\title{
SURVEI MINAT BELAJAR SISWA DALAM MENGIKUTI PEMBELAJARAN PENDIDIKAN JASMANI DI SMPN 30 MAKASSAR
}

\author{
M. Sahib Saleh \\ Universitas negeri Makassar, Email : m.sahib.saleh@unm.ac.id \\ Sunandar Sakria Malinta \\ Universitas negeri Makassar, email : sunandarsakriam2@gmail.com
}

\begin{abstract}
Abstrak
Penelitian ini bertujuan untuk mengetahui Minat Belajar Siswa Dalam mengikuti Pembelajaran Pendidikan Jasmani Di SMPN 30 Makassar. Jenis penelitian ini adalah penelitian deskriptif. Populasi penelitian ini adalah siswa SMPN 30 Makassar.Sampel penelitian terdiri dari 55 orang siswa SMPN 30 Makassar.Teknik pengumpulan data menggunakan observasi dan tes.Teknik analisis data yang digunakan adalah statistic deskriptif menggunakan fasilitas komputer melalui program SPSS.Berdasarkan analisis data diperoleh hasil: Kondisi di SMP Negeri 30 Makassar. Dari 30 butirsoal di temukan 27 yang valid dan 3 yang tidak valid, dapat dilihat bahwa yang mendapat jawaban sangat setuju 546 poin,setuju 932 poin,tidak setuju 147 poin,sangat tidak setuju 25 poin. Dapat ditarik kesimpulan bahwa minat belajar siswa dalam pembejaran pendidikan jasmani berada dalam kategori baik.
\end{abstract}

Katakunci : Minat belajar, pembelajaran

\begin{abstract}
This study aims to determine Student Learning Interest in Participating in Physical Education Learning at SMPN 30 Makassar. This type of research is descriptive research. The population of this study was students of SMPN 30 Makassar. The research sample consisted of 55 students of SMPN 30 Makassar. Data collection techniques used observation and tests. Data analysis technique used was descriptive statistics using computer facilities through the SPSS program. Based on data analysis, the results obtained: in SMP Negeri 30 Makassar. From 30 items found 27 valid and 3 invalid, it can be seen that those who received answers strongly agreed 546 points, agreed 932 points, disagreed 147 points, strongly disagreed 25 points. It can be concluded that the students' interest in learning in physical education is in the good category.
\end{abstract}

Keywords: interest in learning, learning

\section{PENDAHULUAN}

Pembangunan dibidang pendidikan adalah upaya yang sangat menentukan dalam rangka meningkatkan kualitas sumber daya manusia.dimana salah satu upaya itu adalah untuk mewujudkan manusia yang sehat,kuat, terampil dan bermoral melalui pendidikan jasmani. Perkembangan pendidikan diarah gunakan untuk membentuk jasmani yg sehat dan mental yang baik, agar dapat menghasilkan generasi muda yg baik, disiplin dan bertanggung jawab.

Sejak manusia lahir Pendidikan telah ada di muka bumi. Pendidikan dapat diperoleh di mana saja, di rumah, lingkungan sekitar kita, dan pendidikan yang diberikan di sekolah, Pendidikan sangat penting diberikan sejak usia dini. Menurut UU No.20 tahun 2003 tentang 
sistem pendidikan nasional, pendidikan adalah usaha sadar yang terencana untuk mewujudkan suasana belajar dan proses pembelajaran agar peserta didik secara aktif mengembangkan potensi dirinya untuk memiliki kekuatan spiritual keagamaan, pengendalian diri, kepribadian kecerdasan, akhlak mulia, serta keterampilan yang di perlukan dirinya, masyaraka, bangsa dan negara.

Pendidikan jasmani adalah pendidikan melalui aktivitas jasmani dengan berpartisipasi dalam akitvitas fisik, dengan melakukan aktivitas jasmani siswa dapat mengembangkan apresiasi estetis, dengan menguasai keterampilan dan pengetahuan, mengembangkan keterampilan generik serta nilai dan sikap yang positif, dan memperbaiki kondisi fisik untuk mencapai tujuan pendidikan jasmani Samsudin( 2008: 21). Di sekolah olahraga dapat digunakan untuk mengajarkan siswa dalam mengembangkan kepribadian perilaku yang baik dan memelihara serta meningkatkan kesegaran jasmani dalam rangka untuk perbaikan kesehatan dan keterampilan gerak dasar serta berbagai aktivitas jasmani.

Mata pelajaran pendidikan jasmani salah satu mata pelajaran yang ada di dalam kurikulum mulai dari jenjang sekolah dasar hingga sekolah menengah atas. Mata pelajaran ini diberikan kepada siswa malalui aktifitas fisik, secara sistematis dengan bermain dan berolahraga. Pengalaman belajar itu diberikan untuk mengarahkan dan membina, sekaligus membentuk gaya hidup sehat. Selain itu, pendidikan jasmani bertujuan untuk mengembangkan pengetahuan, keterampilan dan berolahraga, meningkatkan kesehatan jasmani, kesegaran jasmani anak, dan tindakana moral anak melalui pelajaran pelajaran pendidikan jasmani, pendidikan jasmani menjadi salah satu media untuk membentuk ketercpaian tujuan pendidikan secara keseluruhan, sehingga dapat memotivasi para siswa dalam pembelajaran pendidikan jasmani.

Pembelajaran merupakan suatu bentuk pertumbuhan atau perubahan dari diri seseorang yang dinyatakan dalam cara bertingkahlaku yang baru berkat pengalaman melalui belajar Oemar hamalik(2005:57). Pembelajaran pendidikan jasmani yang diberikan pada siswa sekolah menengah pertama diharapkan dapat membentuk tubuh yang sehat dan bugar. Selain itu, siswa dapat mengekspresikan perasaannya melalui aktivitas gerak di alam terbuka.

Pendidikan jasmani pada dasarnya merupakan bagian integral dari sistem pendidikan secara keseluruhan, bertujuan untuk mengembangkan aspek kesehatan, kebugaran jasmani, keterampilan berfikir kritis, stabilitas emosional, keterampilan social, penalaran, dan tindakan moral melalui aktivitas jasmani dan olahraga (Depdiknas, 2005 : 2). Sesuai dengan tujuan belajar ialah menghasilkan perubahan perilaku yang melekat pada masing-masing individu, melalui proses belajar tersebut pendidikan jasmani ingin mewujudkan sumbangannya terhadap perkembangan siswa yang bersifat menyeluruh yang dimulai dari adanya sebuah minat. Minat besar pengaruhnya terhadap belajar, karena bila bahan pelajaran yang dipelajari tidak sesuai minat siswa, siswa tidak akan belajar dengan sebaikbaiknya. Minat selain memungkinkan pemusatan pikiran, juga akan menimbulkan kegembiraan dalam usaha belajar. Apabila minat dari siswa tinggi, maka dapat diharapkan pembelajaran pendidikan jasmani akan berlangsung dengan baik. Atau dengan kata lain minat yang muncul dari kebutuhan siswa akan merupakan faktor pendorong bagi anak dalam melaksanakan usahanya.

Minat adalah suatu rasa lebih suka dan rasa keterikatan pada suatu hal atau aktivitas tanpa ada yang menyuruh. Minat pada dasarnya adalah penerimaan akan 
suatu hubungan antara diri sendiri dengan suatu diluar diri (slameto, 2010: 180). Anak yang tidak mengetahui pentingnya belajar akan menciptakan kesulitan dalam meraih prestasi yang maksimal disekolah. Agus sujanto (2009: 92) mengatakan minat adalah suatu pemusatan perhatian yang tidak sengaja yang terlahir dengan melalui partisipasi dalam suatu aktivitas karena minat bersikap khusus tanpa adanya paksaan dari orang lain.

Syaiful Bahri Djamarah (2008: 191), mengatakan bahwa timbulnya minat penuh kemauannya dan yang tergantung dari bakat dan lingkungnnya. Dimana suatu minat dapat di experesikan melalui suatu penyataan yang menunjukkan bahwa siswa lebih menyukai suatu hal dari pada hal yang lainnya, dapat pula manifestasikan belajar disebabkan beberapa hal, antara lain " karena keinginan yang kuat untuk menaikkan martabat atau memperoleh pekerjaan yang baik serta ingin hidup senang dan bahagia". Minat seseorang dapat ditumbuh dan dikembangkan pada diri sendiri tanpa adanya paksaan dari orang lain.

H.Abdul Hadis (2010: 45), minat belajar siswa didik juga dipengaruhi beberapa faktor diantaranya: faktor obyek belajar, metode, strategi, dan pendekatan pembelajaran yang digunakan oleh guru, sikap dan perilaku guru, media pembelajaran, fasilitas pembelajaran, lingkungan belajar, suara guru, dan lainnya.

Hasil observasi yang didapat di SMP N 30 MAKASSAR merupakan salah satu sekolah yang memiliki akreditasi A dan diikuti prestasi dibidang olahraga yang cukup baik. Pada saat proses pembelajaran pendidikan jasmani terlihat banyak siswa/i yang sangat menikmati proses pembelajaran pendidikan jasmani. Tetapi ada juga sebagian siswa yang terlihat jenuh dengan mata pelajaran tersebut.
Pendidikan jasmani pada hakikatnya adalah proses pendidikan memanfaatkan aktivitas fisik untuk menghasilkan perubahan holistic dalam kualitas individu, baik dalam hal fisik, mental, serta emosional. Pendidikan jasmani dilaksakan sebagai salah satu alat dalam mencapai tujuan pendidikan nasional, dengan cakup aspek kongnitif, afektif, prikomotor, dan fisik. Ngalim Purwanto (2007 : 151) pendidikan jasmani adalah salah satu segi pendidikan yang sungguh sungguh penting. Yang tidak dapat terlepas dari segi-segi penddikan yang lain. Pendidikan jasmani merupakan bentuk pembelajaran yang menggunakan aktifitas fisik yaitu belajar untuk bergerak dan belajar melalui gerak.

Menurut Adang Suherman (2003: 23) secara umum tujuan pendidikan jasmani dapat diklasifikasikan ke dalam empat kategori, yaitu:

a. Perkembangan Fisik

Tujuan ini berhubungan dengan kemampuan melakukan aktivitas aktivitas yang melibatkan kekuatan - kekuatan fisik dari dari berbagai organ tubuh seseorang.

b. Perkembangan Gerak

Tujuan ini berhubungan kemampuan melakukan gerak secara efektif, efesien, halus, indah, sempurna.

c. Perkembangan Mental

Tujuan ini berhubungan dengan kemampuan berfikir dan menginterprestasikan keseluruhan pengetahuan tentang pendidikan jasmani ke dalam lingkungannya sehingga memungkinkan tumbuh dan berkembangnya pengetahuan, sikap dan tanggung jawab siswa.

d. Perkembangan Sosial

Tujuan ini berhubungan dengan kemampuan siswa dalam menyesuaikan diri pada suatu kelompok atau masyarakat. 
Minat adalah suatu keadaan dimana seseorang mempunyai perhatian terhadap sesuatu dan disertai keinginan untuk mengetahui dan mempelajari maupun membuktikan lebih lanjut Bimo Walgito (1981 : 38). Dalam belajar diperlukan suatu pemusatan perhatian agar apa yang dipelajari dapat dipahami. Sehingga siswa dapat melakukan sesuatu yang sebelumnya tidak dapat dilakukan. Terjadilah suatu perubahan kelakuan. Perubahan kelakuan ini meliputi seluruh pribadi siswa, baik kognitip, psikomotor afektif.

\section{METODE PENELITIAN}

Penelitian ini merupakan penelitian deskriptif. Menurut Sugiyono (2009: 147),penelitian deskriptif digunakan unuk mendeskripsikan atau menggambarkan data yang telah terkumpul sebagaimana adanya.metode yang digunakan dalam penelitian ini adalah survei. Menurut Suharsimi Arikunto (2010: 152), studi survei adalah salah satu pendekatan penelitian yang pada umumnya digunakan untuk pengumpulan data yang luas dan banyak. Teknik pengumpulan data yang digunakan dalam penelitian ini menggunakan kuesioner atau angket. Penelitian ini bertujuan untuk mengetahui minat belajar siswa dalam mengikuti pembelajaran pendidikan jasmani di SMP NEGERI 30 MAKASSAR.

Definisi operasioanl variable dalam penelitian ini yaitu bagaimana minat siswa dalam mengikuti pembelajaran penjas, Minat dapat juga diartikan sebagai dorongan atau keinginan dalam diri seseorang pada objek tertentu, sehingga tujuan dari penelitian ini yaitu untuk mendapatkan hasil atau skor dari hasil kuisioner tersebut, adapun jenis pengumpulan data dari penelitian ini yaitu melakukan penyebaran kuisioner atau angket. Observasi ialah metode atau cara - cara menganalisis dan mengadakan pencatat secara sistematis mengenai tingkah laku dengan melihat atau mengamati individu atau kelompok secara langsung. Metode ini digunakan untuk melihat dan mengamati secara langsung keadaan dilapangan agar peneliti memperoleh gambaran yang luas tentang permasalahan yang diteliti (Basrowi dan Suwandi, 2008 : 94).

Angket/kuesioner adalah teknik pengumpulan data yang dilakukan dengan cara memberikan seperangkat pertanyaan atau pernyataan kepada orang lain yang dijadikan responden untuk dijawabnya.

Data yang terkumpul tersebut perlu dianalisis secara statistik deskriptif, maupun infrensial untuk keperluan pengujian hipotesis penelitian. Adapun gambaran yang digunakan dalam penelitian ini, sebagai berikut:

1. Analisis data secara deskriptif dimaksud untuk mendapatkan gambaran umum tentang data yang meliputi total nilai, range, rata-rata, standar deviasi, nilai minimum, dan nilai maksimum.

2. Analisis secara infrensial digunakan untuk menguji hipotesis-hipotesis penelitian dengan menggunakan uji korelasi dan regresi. Jadi keseluruhan analisis data statistik yang digunakan pada umumnya menggunakan analisis komputer pada program SPSS dengan taraf signifikan 95\%.

\section{HASIL PENELITIAN DAN PEMBAHASAN}

Deskripsi dalam penelitian adalah data yang diperoleh selama pelaksanaan penelitian meliputi data minat siswa SMP NEGERI 30 MAKASSAR. Data minat siswa meliputi : mean, standar deviation, nilai minimum, nilai maximum yang dapat dilihat pada tabel 1 berikut ini. 
Tabel 1 : Data Minat Siswa

\begin{tabular}{|c|c|c|c|c|c|c|}
\hline $\begin{array}{l}\text { Varia } \\
\text { bel }\end{array}$ & $\begin{array}{c}M \\
\text { ea } \\
n\end{array}$ & $\begin{array}{l}M \\
\text { ed } \\
\text { ia } \\
n\end{array}$ & $\begin{array}{c}\text { Vari } \\
\text { anc } \\
\text { e }\end{array}$ & $\begin{array}{c}\text { Stand } \\
\text { ar } \\
\text { devat } \\
\text { ion }\end{array}$ & $\underset{\text { um }}{\operatorname{minim}}$ & $\begin{array}{c}\text { maxim } \\
\text { um }\end{array}$ \\
\hline $\begin{array}{c}\text { Minat } \\
\text { Belaj } \\
\text { ar }\end{array}$ & $\begin{array}{r}95 \\
6 \\
4\end{array}$ & 55 & $\begin{array}{l}88, \\
902\end{array}$ & 9.429 & 69 & 122 \\
\hline
\end{tabular}

Berdasarkan hasil tabel diatas menunjukkan mean : 95,64, median : 55 , variance : 88,902 , standar devation : 9.429 , minimum : 69, maximum : 122 data tersebut dijumlah menggunakan program SPSS 22.0. Uji validitas dilaksanakan dengan rumus korelasi bivariate person dengan alat bantu program SPSS 22.0. item angket dalam uji validitas dikatakan valid jika $r_{\text {hitung }}>r_{\text {tabel }}$ pada nilai signifikan $5 \%$ sebaliknya, item dikatakan tidak valid jika jikar ${ }_{\text {hitung }}<r_{\text {tabel }}$ pada nilai signifikan $5 \%$. Adapun ringkasan hasil uji validitas sebagai mana data dalam tabel berikut ini.

Tabel.2. hasil uji validitas angket minat belajar Siswa SMP NEGERI 30 MAKASSAR

\begin{tabular}{c|c|c|c}
\hline $\begin{array}{c}\text { No } \\
\text { item }\end{array}$ & $\mathbf{r}_{\text {hitung }}$ & $\mathbf{r}_{\text {tabel5\%(55) }}$ & Keterangan \\
\hline 1 & 285 & 0,266 & Valid \\
\hline 2 & 273 & 0,266 & Valid \\
\hline 3 & 571 & 0,266 & Valid \\
\hline 4 & 434 & 0,266 & Valid \\
\hline 5 & 287 & 0,266 & Valid \\
\hline 6 & 212 & 0,266 & Tidak Valid \\
\hline 7 & 345 & 0,266 & Valid \\
\hline 8 & 573 & 0,266 & Valid \\
\hline 9 & 565 & 0,266 & Valid \\
\hline 10 & 688 & 0,266 & Valid \\
\hline 11 & 695 & 0,266 & Valid \\
\hline 12 & 536 & 0,266 & Valid \\
\hline 13 & 322 & 0,266 & Valid \\
\hline 14 & 535 & 0,266 & Valid \\
\hline 15 & 583 & 0,266 & Valid \\
\hline 16 & 466 & 0,266 & Valid \\
\hline 17 & 434 & 0,266 & Valid \\
\hline 18 & 500 & 0,266 & Valid \\
\hline 19 & 533 & 0,266 & Valid \\
\hline 20 & 358 & 0,266 & Valid \\
\hline & & &
\end{tabular}

\begin{tabular}{c|c|c|c}
\hline 21 & 424 & 0,266 & Valid \\
\hline 22 & 242 & 0,266 & Tidak Valid \\
\hline 23 & 511 & 0,266 & Valid \\
\hline 24 & 543 & 0,266 & Valid \\
\hline 25 & 336 & 0,266 & Valid \\
\hline 26 & 357 & 0,266 & Valid \\
\hline 27 & 469 & 0,266 & Valid \\
\hline 28 & 208 & 0,266 & Tidak Valid \\
\hline 29 & 386 & 0,266 & Valid \\
\hline 30 & 487 & 0,266 & Valid \\
\hline
\end{tabular}

Reliabilitas Instrumen

Pengujian reliabilitas instrument minat belajar pendidikan jasmani siswa menggunakan cronbach's alpha pada program SPSS 22.0. uji reliabilitas dilakukan sebanyak dua kali dengan menggunakan rumus alpha lebih besar dari pada $r_{\text {tabel }}(0,266)$. Berikut:

Tabel 3. Uji Reliabilitas.

\begin{tabular}{|c|c|c|c|}
\hline Variabel & $r_{\text {hitung }}$ & $r_{\text {tabel5\%(55) }}$ & Keterangan \\
\hline $\begin{array}{c}\text { Minat } \\
\text { belajar }\end{array}$ & 0,869 & 0,266 & Reliabel \\
\hline
\end{tabular}

Hasil uji reliabilitas diperoleh nilai koefisien sebesar 0,869.Berdasarkan nilai koefisien reliabilitas tersebut dapat disimpulkan bahwa semua angket dalam penelitian ini reliable atau konsisten, sehingga dapat digunakan sebagai instrument penelitian.

\section{PEMBAHASAN}

Pada penelitian yang berjudul survey tingkat minat belajar pendidikan jasmani siswa SMPN 30 Makassar yang memiliki tujuan mengukur serta mendapatkan data terkait Minat Belajar Pendidikan Jasmani Siswa SMP NEGERI 30 MAKASSAR. Populasi yang digunakan dalam penelitian ini adalah seluruh siswa kelas VII 5 dan VII 11 yang tercatat di SMP NEGERI 30 MAKASSAR yang terdiri dari VII 5 : 34 siswa dan VII 11 : 21 siswa. Pengambilan sampel menggunakan sebagian atau wakil 
populasi yang akan kita teliti ( SuharsimiArikunto, 2006 : 109).

Dalam pengambilan sampel jika subyeknya kurang dari 100, maka lebih baik diambil semua sehingga penelitiannya merupakan penelitian populasi, namun jika subyeknya lebih dari 100, maka sampel yang diambil antara $10-15 \%$ atau $20 \%-25 \%$ atau lebih (SuharsimiArikunto, 2002:112).

Dikarenakan jumlahpopulasi lebih dari 100 maka peneliti mengambil sampel sebanyak $25 \%$ dari jumlah populasi. Setelah mendapatkan sampel yang akan diteliti, peneliti kemudian menyebarkan angket minat belajar pendidikan jasmani yang digunakan untuk mengukur tingkat minat siswa dalam pembelajaran pendidikan jasmani pada siswa SMP NEGERI $\quad 30$ MAKASSARPenelitian menggunakan Uji validitas dan UjiReabilitas, hal ini dilakukan untuk mengetahui valid tidaknya, serta reliable atau tidaknya angket yang akan dijadikan tolak ukur untuk mengukur tingkat minat siswa dalam mengikuti pembelajaran pendidikan jasmani menggukankan program SPSS 22.0. Jumlah butir pertanyaan pada angket yang diajukan peneliti pada siswa SMP NEGERI 30 MAKASSARyaitu sebanyak 30 butir pertanyaan.

Berdasarkan hasil seleksi pengujian validitas instrument dilakukan sebanyak dua kali, peneliti mendapatkan 27 pernyataan valid dan 3pernyataan yang tidak valid. Sedangkan pernyataanvalid dianggap mampu menjadi tolak ukur penelitian.

Uji validitas dilaksanakan dengan rumus korelasi bivariate person dengan alat bantu program SPSS 22.0. item angket dalam uji validitas dikatakan valid jika $r_{\text {hitung }}>r_{\text {tabel }}$ pada nilai signifikan $5 \%$ sebaliknya, item dikatakan tidak valid jika jikar hitung $<r_{\text {tabel }}$ pada nilai signifikan 5\%.Adapun penjelasan mengenai hasil dari penelitian ini adalah minat belajar pendidikan jasmani siswa SMP NEGERI 30 MAKASSARberada dalam kategori baik. Hasil dari pengumpulan skor angket siswa ditemukan untuk butir pertanyaan yang mendapat Jumlah jawaban dengan skor 4 sebanyak 546, Jumlah jawaban dengan skor 3 sebanyak 932, Jumlah jawaban dengan skor 2 sebanyak 147, Jumlah jawaban dengan skor 1 sebanyak 25 . Berdasarkan hasil yang diperoleh menunjukkan bahwa minat siswa SMPN 30 MAKASSAR dalam mengikuti pembelajaran jasmani berada pada kategori baik .

Minat merupakan unsur terpenting dalam suatu proses untuk melakukan suatu kegiatan. Minat dipengaruhi oleh beberapa faktor diantaranya faktor instrinsik dan faktor ekstrinsik. Hasil ini menunjukkan seberapa besar minat siswa dalam mengikuti pembelajaran jasmani dan apa saja faktor yang mempengaruhinya. Minat siswa dalam mengikuti pembelajaran jasmani sangat berpengaruh terhadapkeberhasilan pembelajaran yang dikemas oleh guru. Hal ini dikarenakan siswa sebagai pelaku pembelajaran menjadi bagian terpenting dalam keberhasilan pembelajaran. Sehingga pembelajaran harus dikemas sedemikian rupa dan berusaha menumbuhkan minat belajar siswa agar pembelajarandapat berjalandengan maksimal.

Permasalahan yang sering muncul dalam pembelajaran pendidikan jasmani harus mampu diminimalisiroleh guru agar siswa dapat tertarik mengikuti pembelajaran pendidikan jasmani dengan aktif. Permasalahan yang beragam dari siswa maupun pengemasan pembelajaran akan mempengaruhi minat siswa dalam mengikuti pembelajaran. Menurut B. Suryobroto (1988: 109) minat kecenderungan dalam diri individu untuk tertarik pada subyek atau menyenangi suatu obyek. Hal ini menunjukkan bahwa 
seberapa besar minat siswa dalam mengikuti pendidikan jasmani merupakan cerminan seberapa besar siswa tertarik terhadap pembelajaran pendidikan jasmani. Keadaan ini dapat dipengaruhi oleh faktor dari dalam maupun dari luar. Minat siswa yang tinggi akan tercermin dengan tingkat partisipasi siswa dalam pembelajaran pendidikan jasmani yang tinggi. Sebaliknya jika minat siswa rendah maka dapat tercermin dalam partisipasi siswa dalam pembelajaran yang rendah. Menurut Super dan Crites seperti dikutip oleh Killis (1988:25) dijelaskan bahwa minat itu dipengaruhi oleh banyak faktor. Kondisi psikologis siswa menjadi patokan utama untuk seberapa besar minat siswa, dengan hal ini maka seorang guru harus mampu mengontrol dan menciptakan suasana pembelajaran yang meyenangkan dan menarik perhatian siswa dalam mengikuti pembelajaran. Hasil penelitian menunjukkan bahwa faktor ekstrinsik lebih besar dari faktor intrinsik dalam mempengaruhi minat belajar siswa. Hal ini menunjukkan bahwa peranan guru dan fasilitas pembelajaran lebih, mempengaruhi siswa dibandingkan dengan perhatian, perasaan senang dan bentuk aktivitas siswa dalam pembelajaran.

Peranan guru dalam pembelajaran sangatlah sentral untuk mengemas pembelajaran dan mengontrol kondisi kelas. Hal ini menunjukkan bahwa seorang guru harus mampu menciptakan suasana pembelajaran dengan memanfaatkan fasilitas dan mengontrol psikologis siswa agar siswa memiliki minat belajar yang tinggi. Minat belajar yang tinggi akan mambantu siswa untuk aktif dalam pembelajaran dan memiliki kesempatan untuk menguasai keterampilan yang diajarkan dan meraih prestasi belajar yang maksimal.
KESIMPULAN DAN SARAN

Kesimpulan

Setelah menganalisis data penelitian tentang survei minat belajar siswa dalam mengikuti pembelajaran pendidikan jasmani di SMPN 30 Makassar maka hasil penelitian dapat disimpulkan sebagai berikut :

1. Tingkat Minat siswa dalam mengikuti pembelajaran pendidikan jasmani berada dalam kategori baik.

2. Faktor yang dapat mempengaruhi siswa dalam mengikuti pembelajaran pendidikan jasmani adalah masih terbatasnya sarana dan prasana yang mendukung.

\section{Saran}

1. Sehubungan dengan minat siswa dalam pembelajaran penjas, maka sebaiknya pihak sekolah memberikan ruang yang lebih untuk siswa dalam mengembangkan bakatnya khususnya untuk mata pelajaran pendidikan jasmani.

2. Pengadaan sarana dan prasarana di sekolah dapat menunjang peningkatan prestasi siswa terhadap mata pelajaran pendidikan jasmani.

3. Sering mengikut sertakan siswa dalam kegiatan olahraga ditingkat Kecamatan, Kabupaten, maupun tingkat Provinsi.

\section{DAFTAR PUSTAKA}

Hastuti, Tri Ani, (2008). Kontribusi Ekstrakulikuler Bola Basket Terhadap Pembibitan Atelet dan Peningkatan Kesegaran Jasmani. Jurnal Pendidikan Jasmani Indonesia (nomor 1, April tahun 2008). HIm 62.

Hurlock,Elizabet B,1993, Perkembangan Anak Jilid 2. Jakarta: Erlangga.

Ketut, Sukardi,Dewa. 1993. Analisis Inventori Minat dan Keperibadian. Jakarta: Rineka Cipta.(1984). 
Bimbingan Belajar Di SekolahSekolah. Jakarta: Ghalia Indonesia.

Pasaribu dan Simanjuntak. 1983. Proses Belajar Mengajar. Bandung : Tarsit Porter dan Hernaci. 2001. Qoutum Learning. Bandung: Kaifa.

Purwanto,Ngalim. (2007). Ilmu Pendidikan Teoritis dan Praktis. Bandung : PT Remaja Rosdakarya.

Poerbakawatja Soegarda dan H. A. H. Harahap. 1980. Ensiklopedia Pendidikan. Jakarta: Gunung Agung.

RahmanAbror Abdul, (1998). Psikologi

Pendidikan. Yogyakarta :

TiaraWacana.

Riduwan. (2015). Dasar-Dasar Statistika, Bandung: Alfabeta.

Slameto (2010). Belajar dan Faktor-Faktor Yang mempengaruhinya. Jakarta : Rineka Cipta.

Sudjiono Anas, (2009). Pengantar Statistik Pendidikan. Jakarta : PT. Raja Gafindo Persada.

Sugiyono, (2017). Metode Penelitian Pendidikan (Pendekatan Kuantitatif, Kualitatif, dan R\&D). Bandung: ALFABETA, CV.

Sujanto,Agus. (2009). Psikologi Umum. Jakarta : Bumi Aksara.

Supriyadi, (2017). Survei Minat Siswa Terhadap Pelajaran Pendidika Jasmani Pada Madrasah Aliyah Negeri 1 Kota Magelang Tahun 2007. Skripsi Magelang : FIK Universitas Negeri Semarang.

Tidjan. 1981. Bimbingan dan Konseling Sekolah. Yogyakarta : IKIP Yogyakarta. Walgito Bimo, (2004). Bimbingan Konseling di Sekolah. Yogyakarta: Andi offset.

Wayan Nur Kancana dan P.P.N. Sumartana. 1982. Evaluasi Pendidikan. Suarabaya: Usaha Nasional. 